\title{
Effect of maturity and storage duration on plantain (Plantago lanceolata) silage quality
}

\author{
Nur Rizqi Bariroh $^{1^{*}}$, Racheal Bryant ${ }^{2}$, and Alistair Black ${ }^{2}$ \\ ${ }^{1}$ AIAT - East Kalimantan, Jl. PM Noor- Sempaja, Samarinda, East Kalimantan, Indonesia \\ ${ }^{2}$ Faculty of Agriculture and Life Sciences, PO Box 85084, Lincoln University, Christchurch, New \\ Zealand
}

\begin{abstract}
Plantain (Plantago lanceolata) is known as a plant which is able to mitigate $\mathrm{N}$ leaching to the soil. Plantain also has high in nutrition and palatable. Unfortunately, nutrition content of plantain if it is conserved as silage is none. To address this question, the effect of regrowth stage and storage duration on ensiling properties of plantain were compared using replicated mini-silos $(500 \mathrm{~g} \mathrm{FW})$. A factorial completely randomized design with three levels of regrowth stage (4-leaf, 5-leaf and 6-leaf appearance) and 4 levels of storage durations $(80,120$, 150,180 days) and five silo replicates was used. In this study 6-leaf had more fibre and less sugars. Ensiling properties was affected by pre and post-harvest management $(\mathrm{P}<0.001)$. Late harvest $(6 \mathrm{~L})$ had higher $\mathrm{pH}$ and lactic acid than early harvest $(4 \mathrm{~L}$ or $5 \mathrm{~L}$ ). The nutritive value of plantain silage was better at early harvest than that of at late harvest $(\mathrm{P}<0.05)$. It can be concluded that ensiling plantain at earlier regrowth stage of improved the quality of plantain silage. This study suggests that silage made from the early regrowth stage can be stored until 120 days to produce good quality of silage.
\end{abstract}

\section{Introduction}

Dairy farming industry have negative effect to the soil to the environment due to nitrogen leaching to the soil [1]. Several research showed that plantain might be able to lowering nitrogen concentration on pasture $[2,3,4]$. Besides, plantain has high in nutritive value and palatable [5]. Like other forage, plantain can be conserved as silage when the production is abundance and it could be utilize as supplementary feed during scarcity [6]. However little research support this statement. Factors that manipulate the quality of plantain silage is questionable.

Good quality silage has only slighty lower in feed value than the fresh forage. According to Mahanna and Chase [7], stage of maturity and duration of storage which are controllable factor influence the silage quality. Further stated, season which is uncontrollable factor affect the quality of silage as well. Nutritive value of forage determined by climate, directly or indirectly [8]. Maturity stage plays an important role in silage quality because plant tissue maturity alters the fermentable sugars availability and

* Corresponding author: rizqibarir@yahoo.com 
fermentable sugar is used by microorganism in silage [7]. Xie et al. [9] showed that there was a negative effect on wheat silage quality in term of its fermentation and nutrition quality. Duration of storage is no less important of silage itself. Prolonged storage in a mini silo of corn silage reduced its nutritive value [10]. Wheat and corn silage had a decrease in a dry matter and NDF digestibility with longer storage but this was not consistent among silage types [11].

However, there has no research of fermentation characteristics and nutritive value of plantain silage influenced by regrowth stage and storage duration. This study aimed to investigate the effect of regrowth stage and storage duration on the fermentation characteristics and nutritive value of plantain (Plantago lanceolata) silage in warm temperature (late spring).

\section{Materials and methods}

\subsection{Site and experimental design}

This study was conducted on 14 November 2016 - 26 June 2017 at the Lincoln University Research Dairy Farm (LURDF) Canterbury, New Zealand (4338S', 172 $27 \mathrm{E}^{\prime}$ ). Experimental design used was a 3 x 4 factorial completely randomised design. Factor 1 was maturity stage (4-leaf appearance, 5-leaf appearance and 6-leaf appearance. Factor 2 was storage duration $(90,120,150,180$ days). Replicates were 5 mini silos in each treatment, giving a total of 60 mini silo's.

\subsubsection{Silage harvesting}

Plantain was harvested on 14 November 2016. Plantain area was regrowth until reach treatment maturity stage. Urea was used as fertilizer at $25 \mathrm{~kg} \mathrm{~N} / \mathrm{ha}$. The regrowth stage reached target on 14 (4-leaf), 21 (5-leaf) and 28 (6-leaf) December 2016. The leaf stage was confirmed by counting the number of developed leaves per shoot on 20 random plants.

In order to maximise sugar, plantain was harvested between 13.00 and $14.00 \mathrm{~h}$, then wilted for 24-48 hours until the dry matter was suitable for ensiling which was around 30\% [12]. The dry matter percent was confirmed by oven drying a sub-sample of $50 \mathrm{~g}$ fresh weight (FW) for 48 hours at $60^{\circ} \mathrm{C}$. A $200 \mathrm{~g}$ of wilted plantain was stored in a freezer ($20 \mathrm{oC})$ for freeze drying and further herbage analysis.

Three random quadrats $(0.2 \mathrm{~m} 2)$ was used to measure DM yield of plantain. Harvested plantain was cleared from weeds and soil and the samples were dried in oven at $60 \mathrm{o} \mathrm{C}$ for 48 hours. Furthermore, prior ensiling, any weed was removed from wilted plantain. Mini silo was a 35 micron polyethylene plastic bag $(23 \times 38 \mathrm{~mm})$. The weight of wilted plantain used was $500 \mathrm{~g}$ and pressed in plastic bag and sealed to exclude air. Wilted plantain was compacted and densely and plastic bag was twisted three times before sealing with adhesive tape [13]. Plastic bag was twisted again and retaped, the inserted to the second plastic bag, twisted and retaped. All bags were stored in black plastic drum in a shed for 90, 120, 150 and 180 days.

\subsubsection{Herbage analysis}

Five replicate silos from each leaf stage were removed at each treatment storage date. Identifying of mould presence was conducted as visual assessment of the silage. 
Playne and Mc Donald method was used to determine the $\mathrm{pH}$ and buffering capacity [14]. The buffering capacity was expressed as meq. of alkali required to change the $\mathrm{pH}$ from 4 to 6 per $100 \mathrm{~g}$ of dry matter (meq./100 $\mathrm{g} \mathrm{DM}$ ).

A Randox kit (Rx Daytona, UK) was used to measure ammonia and volatile fatty acid (VFA). The procedure was a 20 grams of fresh silage were macerated with $100 \mathrm{~mL}$ of distilled water and then left to stand for 30 minutes. Two $\mathrm{ml}$ of solution from the macerator then had NH3-N, total VFA and lactic acid.

The dry matter percentage was determined by weighing approximately $50 \mathrm{~g} \mathrm{FW}$ sample and oven drying at $60^{\circ} \mathrm{C}$ for 48 hours. Wet chemistry was used to analyse nutritive characteristics of fresh plantain and plantain silage. All samples were freeze dried then they were milled through a $1 \mathrm{~mm}$ screen centrifugal rotor mill (Retsch-ZM, Haan, Germany). The botanical composition of the silage was then measured by sorting $25 \mathrm{~g}$ into stems and leaves then oven drying for 48 hours at $60^{\circ} \mathrm{C}$. The proportion of the leaves and stem were calculated on a DM basis

Acid detergent fibre (ADF) was determined gravimetrically by the addition of $1 \mathrm{~g}$ of sample with $50 \mathrm{ml}$ of detergent solution (cetyltrimethylammonium bromide and sulphuric acid), then heated for 1 hour. The detergent was then filtered to waste using hot water before rinsing with acetone. Afterwards, it was dried at $100^{\circ} \mathrm{C}$ overnight and ashed at $500^{\circ} \mathrm{C}$ for two hours. The difference in weight between the sample dry weight and the sample ash weight over the sample weight times DM (residue dry matter) was recorded as ADF\% [15]. Neutral detergent fibre (NDF) was determined by extracting $1 \mathrm{~g}$ of sample with sodium lauryl phosphate, ammonium pentaborate and EDTA. The NDF\% was calculated by subtracting the dry weight with the ash weight over sample weight times rDM [16].

An elementor analyser Vario Max $\mathrm{CN}$ with catalytic tube combustion under an oxygen supply and high temperature was used to measure crude protein (CP). It was based on total $\mathrm{N}$ concentration. Crude protein was calculated by multiplying total $\mathrm{N}$ x rDM x 6.25. Water soluble carbohydrate (WSC) was analysed by extracting in ethanol and water for low molecular weight (LMW) and high molecular weight (HMW) using respective sucrose and inulin standards [17]. WSC was measured for fresh and wilted plantain

Secondary metabolites were extracted from 3 replicates of plantain $4 \mathrm{~L}$ and $6 \mathrm{~L}$ silage stored for 90 and 180 days by adding $1.5 \mathrm{ml}$ of $100 \%$ methanol. Aucubin and catalpol were determined by adding $0.5 \mathrm{ml}$ of the extracted mixture of samples to $0.5 \mathrm{ml}$ of water, mixing well and filtering through a $0.45 \mu \mathrm{m}$ nylon membrane syringe filter into $2 \mathrm{ml}$ HPLC vials and stored at $-20^{\circ} \mathrm{C}$ before HPLC analysis. Acteoside was measured by filtering the extracted mixture of samples with a $0.45 \mu \mathrm{m}$ nylon membrane syringe filter without dilution into a HPLC vial, and then stored in $-20^{\circ} \mathrm{C}$ until HPLC analysis [18].

The sample of dry matter digestibility was digested for 48 hours at $50^{\circ} \mathrm{C}$ with acidified pepsin, incubated at $50^{\circ} \mathrm{C}$ and then digested for 48 hours at $40^{\circ} \mathrm{C}$ with a buffered cellulase solution [19]. In vitro dry matter digestibility was measured by using the formula below.

$$
\text { In vitro } \mathrm{DMD}(\%)=100 *[(\mathrm{rDM} / 100) * \mathrm{SW}-\mathrm{rW}] /[(\mathrm{rDM} / 100) * \mathrm{sW}]
$$

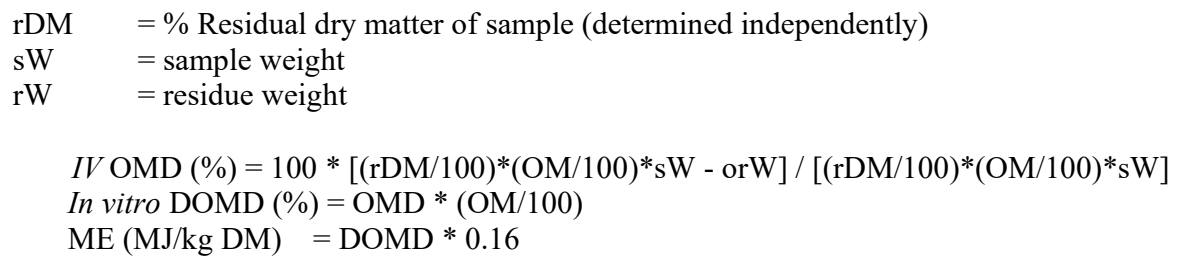


IVOMD = In vitro organic matter digestibility

$\mathrm{OM}=\%$ Organic matter of sample (determined independently)

$\mathrm{rDM}=\%$ Residual dry matter of sample (determined independently)

$\mathrm{sW} \quad=$ sample weight

orW = organic residue weight

DOMD $=$ Digestible Organic Matter in Dry matter

ME $\quad=$ Metabolizable Energy

MJ = Mega joule

\subsection{Meteorological data}

The data of meteorology was from the National Climate Database (http://cliflo.niwa.co.nz).

The calculation of the growing degree day (GDD) was using the formula below.

$$
\text { GDD }=\frac{\text { Temperature maximum }+ \text { temperature minimum }}{2}-\text { base temperature }
$$

The base temperature used for plantain was $5^{\circ} \mathrm{C}$ based on [20].

\subsection{Statistical analysis}

Data collected from fresh plantain and plantain silages was analysed by using the statistical package Genstat version 18 (VSN International Ltd, 2015) was used as analysis tool. Fresh plantain (leaves, seed heads, shoots, production) was analysed by using a one-way ANOVA. Fresh plantain was as fixed terms and the replicates as random terms.

Two-way factorial ANOVA (3 regrowth stages $\mathrm{x} 4$ storage durations) was used to analyse data of plantain silages. The model used to analyse the data was stage maturity $\mathrm{x}$ storage duration as the fixed term and replications as block or random term.

\section{Results and discussion}

\subsection{Climate conditions}

Air temperature during harvesting at 4-leaf and 6-leaf were not too different. However, the air temperature during wilting was at above $20^{\circ} \mathrm{C}$ among the treatments (Table 1.)

Table 1. Air temperature during harvest and when wilting the herbage

\begin{tabular}{|c|c|c|c|c|}
\hline Plantain & Harvest date & $\begin{array}{c}\text { Air temperature } \\
\text { during harvesting } \\
\left({ }^{\circ} \mathrm{C}\right)\end{array}$ & $\begin{array}{c}\text { Air temperature } \\
\text { during wilting } \\
\left({ }^{\circ} \mathrm{C}\right)\end{array}$ & Ensiling date \\
\hline $4 \mathrm{~L}$ & $\begin{array}{l}\text { 14 December } \\
2016\end{array}$ & 17.4 & 20.7 & $\begin{array}{c}15 \text { December } \\
2016\end{array}$ \\
\hline $5 \mathrm{~L}$ & $\begin{array}{l}21 \text { December } \\
2016\end{array}$ & 23.1 & 20.4 & $\begin{array}{c}22 \text { December } \\
2016\end{array}$ \\
\hline $6 \mathrm{~L}$ & $\begin{array}{l}28 \text { December } \\
2016\end{array}$ & 17.4 & 21.1 & $\begin{array}{c}30 \text { December } \\
2016\end{array}$ \\
\hline
\end{tabular}

*Where $4 \mathrm{~L}=4$-leaf, $5 \mathrm{~L}=5$-leaf appearance, $6 \mathrm{~L}=$ six-leaf appearance. The average temperatures in this study were $19.6^{\circ} \mathrm{C}$ and $9.3^{\circ} \mathrm{C}$ for the maximum and minimum temperatures, respectively (Figure 1). The growing degree day (GDD) for plantain $4 \mathrm{~L}$ was 373.4 , for plantain $5 \mathrm{~L}$ was 471.3 and plantain $6 \mathrm{~L}$ was 572.9 . 


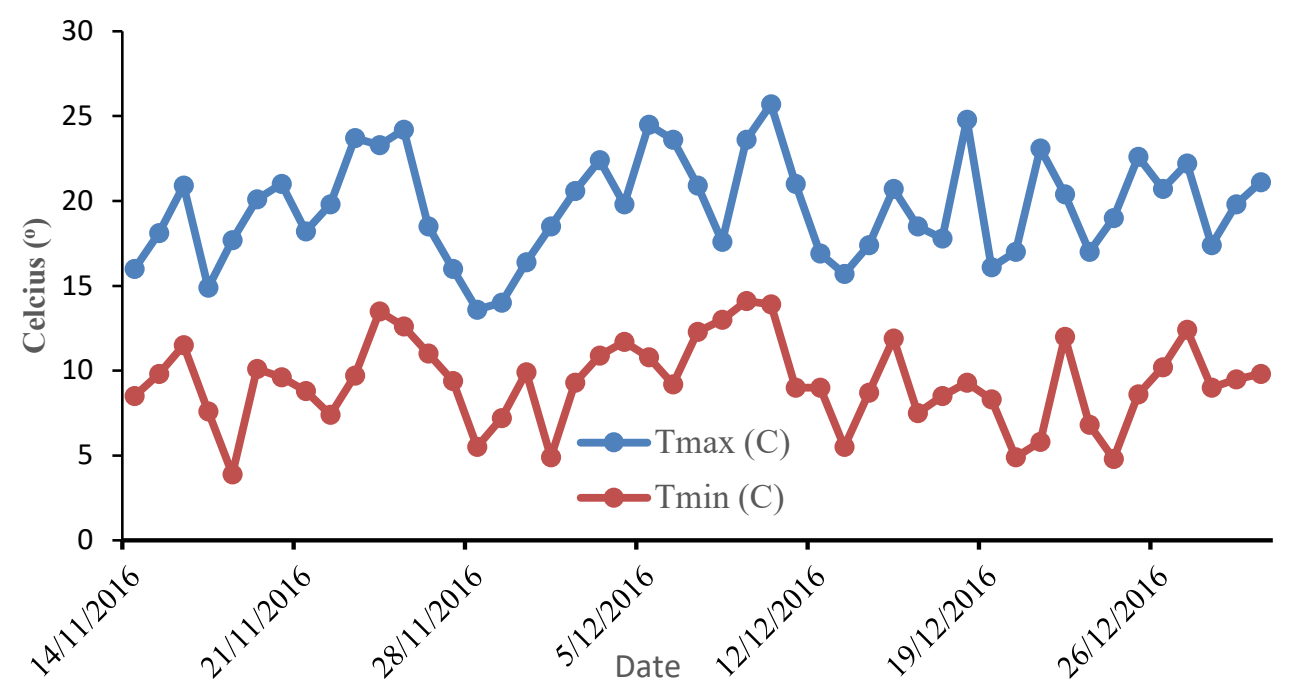

Fig. 1. Temperature maximum and minimum from 14 November - 30 December 2016 for plantain. Data was taken from the National Climate Database (Cliflo).

\subsection{Plantain characteristics}

The difference in yield among the regrowth stages was found (Table 2.). The yield at $6 \mathrm{~L}$ was $1000 \mathrm{~kg} / \mathrm{DM}$ greater than at $4 \mathrm{~L}$ or $5 \mathrm{~L}$. Increasing regrowth interval resulted in the increasing the total of stems and seed heads. The stems and seed head was $50 \%-55 \%$ for the $4 \mathrm{~L}$ and 51 but for $6 \mathrm{~L}$ it was more than $70 \%$ (Table 4 ).

\subsection{Nutritive value of fresh plantain}

Fresh or wilted plantain had relatively low in nutritive value with the digestibility less than $70 \%$ and $\mathrm{ME}$ at $10 \mathrm{MJ} \mathrm{ME} / \mathrm{kg} \mathrm{DM}$ (Table 3). Increasing regrowth stages resulted in decreasing of crude protein and OM. The DM content of wilted plantain was between $30 \%$ and $40 \%$ prior to ensiling. The major substrates for LAB namely crude protein and WSC were relatively low. In term of secondary metabolites, their percentages at early regrowth stage were higher than those of late harvested.

Table 2. Plantain characteristics

\begin{tabular}{|c|c|c|c|c|}
\hline Treatment & $\begin{array}{c}\text { Production } \\
\text { (kg DM/ Ha) }\end{array}$ & $\begin{array}{c}\text { Number of leaves/ } \\
\text { plant (leaves) }\end{array}$ & $\begin{array}{c}\text { Number of } \\
\text { shoots/ } \\
\text { plant (shoot) }\end{array}$ & $\begin{array}{c}\text { Number of } \\
\text { seedheads/ } \\
\text { plant(seedhead) }\end{array}$ \\
\hline Plantain 4L & 1476 & $3.98^{\mathrm{c}}$ & $10.9^{\mathrm{a}}$ & $19.1^{\mathrm{a}}$ \\
\hline Plantain 5L & 1546 & $5.00^{\mathrm{b}}$ & $12.6^{\mathrm{a}}$ & $25.2^{\mathrm{ab}}$ \\
\hline Plantain 6L & 2435 & $6.03^{\mathrm{a}}$ & $15.5^{\mathrm{b}}$ & $30.1^{\mathrm{b}}$ \\
\hline SEM & 428.4 & 0.089 & 0.68 & 2.16 \\
\hline P value & 0.153 & $<.001$ & $<0.001$ & 0.003 \\
\hline
\end{tabular}

*Where $4 \mathrm{~L}=$ four leaves appearance, $5 \mathrm{~L}=$ five leaves appearance and $6 \mathrm{~L}=$ six leaves appearance. Different notations in the same column show significant results $(\mathrm{P}<0.001), \mathrm{SEM}=$ standard error of means 


\subsection{Fermentation characteristics of plantain silage}

Visual assessment of plantain silage showed that early harvested plantain had lower percentage of mould at its surface area. The silage was not attractive because the colour was dark brown but the smell was still sweet. Byssochlamys nivea was the mould in this silage which is responsible for spoilage and the degradation of silage.

Generally, the $\mathrm{pH}$ was high with average of 5.16 (Table 4). Silage $\mathrm{pH}$ was only affected by regrowth stage $(\mathrm{P}<0.05)$, where the highest was at $6 \mathrm{~L}$. For $\mathrm{BC}$, there was an interaction between maturity and storage duration, with the highest $\mathrm{BC}$ reached at $4 \mathrm{~L}$ stored for 150 and 180 days. Significant result of total VFA, lactic acid and propionic acid were at early regrowth stage. Longer storage duration decreased total VFA and there was an interaction between regrowth stage and storage duration. Lactic acid and propionic acid were not affected by storage duration.

The percentage of $\mathrm{NH}_{3} \mathrm{~N}$ was good $(<1 \%)$. It was affected by storage duration. There was no interaction between regrowth stage and storage duration with the $\mathrm{NH}_{3}-\mathrm{N}$ value. The butyric acid percentage was below $0.5 \%$ and there was no difference among the treatments.

Degree of acidity or $\mathrm{pH}$ is essential for silage. Low $\mathrm{pH}$ under anaerobic condition is needed to stimulate and sustain intensive and lasting lactic acid fermentation to depress plant enzyme activities and unwanted microorganism [21]. Good preservation of silage aimed to decrease spoilage by moulds, yeast or harmful bacteria and to prevent DM loss. The standard $\mathrm{pH}$ silage is 4.7 [22]. Silage $\mathrm{pH}$ and lactic acid produced by LAB are closely link. There are several factors influence $\mathrm{pH}$, the LAB activity and lactic acid production such as protein, fermentable carbohydrate, buffering capacity and secondary compounds.

The low $\mathrm{pH}$ need growth fast of LAB to produce Lactic acid. The high $\mathrm{pH}$ in this study because of the low production of lactic acid which was below 1\% of DM. The LAB growth might be inhibited by the low water soluble protein (WSC) or by sorbitol sugar [23], which is not sugar source for silage bacteria. The other possible reason of low lactic acid is the protein content was low and unavailable as a part of protein would have been bound in stem material.

A challenge with the mini-silo was the exclusion of oxygen. Mould percentage in mini silo increased with the increased with regrowth stage, indicating the presence of oxygen. At the late regrowth stage, the high proportion of stems was contributed the mould growth as the stalks were difficult to compress and remove air. Besides, plastic used in this study was at $70 \mu \mathrm{m}$ thickness which may not have prevented the ingress of oxygen [24]. The high $\mathrm{pH}$ and $\mathrm{BC}$ of silage in this study might affect the aerobic stability of silage when expose to air. High $\mathrm{pH}$ initiate the aerobic microbial activity on the exposure of silage to air [25]. Spoiled silage can be detected through its odour, due to high butyric acid content $(>1 \%)$ [26]. In this study plantain silage had sweet aroma and low butyric acid $(, 0.5 \%)$. It indicates that plantain can be ensiled at high $\mathrm{pH}$.

Plant proteases may have been inactivated by initial high $\mathrm{pH}$. Inactivated proteases reduced the extent of protein degradation and maintaining a higher $\mathrm{pH}$. Antimicrobial compound such as aucubin or acteoside cause proteolysis restriction [27]- Slow protein degradation by rumen bacteria in in vitro fermentation studies due to antimicrobial compound was also reported [28]. Inactivated proteases might have occurred at the beginning of the fermentation phase as secondary compound disappeared during storage duration. Prolong storage did not cause significant damage in fermentation characteristics. This result support with Stewart [6] who reported that plantain silage can be stored after 180 days.

A longer storage duration did not change acetic acid percentage. Regrowth stage affected acetic acid percentage where the late harvested resulted in higher lactic acid. The possible reason is higher levels of oxygen enter mini silo that increase higher lactic acid. Propionic acid did not change with the longer storage duration. Weinberg and Muck 
[29] opined that propionic bacteria are only effective in improving the aerobic stability in slowly acidifying silages because the available strains did not produce propionic acid below $\mathrm{pH} 4.8$ [30].

Table 3. Nutritive characteristics (\% of DM) of fresh and wilted plantain four leaves appearance (4L), five leaves appearance $(5 \mathrm{~L})$ and six leaves appearance $(6 \mathrm{~L})$

\begin{tabular}{|c|c|c|c|c|c|c|}
\hline \multirow{2}{*}{ Variable } & \multicolumn{2}{|c|}{ Plantain 4L } & \multicolumn{2}{c|}{ Plantain 5L } & \multicolumn{2}{c|}{ Plantain 6L } \\
\cline { 2 - 7 } & Fresh & Wilted & Fresh & Wilted & Fresh & Wilted \\
\hline Dry matter (\%) & 18.9 & 38.1 & 22.2 & 30.4 & 22.2 & 35.8 \\
\hline Organic matter (\%) & 81.1 & 90.7 & 90.4 & 90.1 & 90.1 & 90.3 \\
\hline Neutral detergent fibre (\%) & 34.2 & 44.7 & 39.5 & 43.2 & 43.6 & 45.3 \\
\hline Acid detergent fibre (\%) & 25.1 & 32.1 & 27.9 & 31.6 & 31.1 & 32.3 \\
\hline Crude protein (\%) & 12.2 & 11.3 & 11.7 & 11.1 & 10.4 & 9.6 \\
\hline Water soluble carbohydrate (\%) & 3.01 & 4.12 & 3.63 & 3.5 & 4.66 & 4.03 \\
\hline DM digestibility (\%) & 68.5 & 66.7 & 68.1 & 66.7 & 65.6 & 64.5 \\
\hline OM digestibility (\%) & 69.4 & 67.2 & 69.5 & 68.5 & 67.5 & 66.2 \\
\hline Digestible OM in the DM (\%) & 56.3 & 60.9 & 62.8 & 61.7 & 60.8 & 59.8 \\
\hline $\begin{array}{c}\text { Metabolisable Energy } \\
\text { (MJ ME/kg DM) }\end{array}$ & 9 & 9.74 & 10 & 9.87 & 9.73 & 9.57 \\
\hline Aucubin (mg/g) & 0.34 & - & - & - & 0.21 & - \\
\hline Catalpol (mg/g) & 1.58 & - & - & - & 1.40 & - \\
\hline Acteoside (mg/g) & 18.16 & - & - & - & 16.49 & - \\
\hline
\end{tabular}

$\mathrm{DM}$ is dry matter, $\mathrm{OM}$ is organic matterMJ $\mathrm{ME} / \mathrm{kg} \mathrm{DM}=$ Megajoule metabolisable energy/kilogram dry matter, $\mathrm{mg} / \mathrm{g}=$ milligram/gram 
Table 4. Fermentation characteristics of plantain four leaves appearance ( $4 \mathrm{~L})$, five leaves appearance $(5 \mathrm{~L})$, six leaves appearance $(6 \mathrm{~L})$ silage $(\% \mathrm{DM})$

\begin{tabular}{|c|c|c|c|c|c|c|c|c|c|c|c|}
\hline Treatment & $\begin{array}{c}\text { Storage } \\
\text { (day) }\end{array}$ & $\begin{array}{c}\text { BC } \\
\text { (meq./100g } \\
\text { DM) }\end{array}$ & pH & $\begin{array}{l}\text { Total } \\
\text { VFA } \\
(\%) \\
\end{array}$ & $\begin{array}{l}\text { Acetic } \\
\text { acid } \\
(\%) \\
\end{array}$ & $\begin{array}{c}\text { Butyric } \\
\text { acid (\%) }\end{array}$ & $\begin{array}{l}\text { Lactic } \\
\text { acid } \\
(\%) \\
\end{array}$ & $\begin{array}{c}\text { Propionic } \\
\text { acid (\%) }\end{array}$ & $\begin{array}{c}\mathrm{NH}_{3}-\mathrm{N} \\
(\% \text { of } \\
\text { total N) } \\
\end{array}$ & $\begin{array}{c}\text { Stem } \\
\text { proportion } \\
(\%)\end{array}$ & $\begin{array}{c}\text { Visual } \\
\text { assessment of } \\
\text { mould (\%) } \\
\end{array}$ \\
\hline \multirow[t]{4}{*}{$4 \mathrm{~L}$} & 90 & $210.3^{b}$ & 4.91 & $1.01^{\mathrm{a}}$ & $0.43^{\mathrm{a}}$ & 0.03 & $0.54^{\mathrm{a}}$ & 0.00 & 2.05 & 52.7 & $20^{\mathrm{ab}}$ \\
\hline & 120 & $157.7^{\text {a }}$ & 5.05 & $0.56^{\text {bcd }}$ & $0.22^{\mathrm{e}}$ & 0.01 & $0.27^{\text {bcd }}$ & 0.00 & 1.45 & 48.1 & $20^{\mathrm{abc}}$ \\
\hline & 150 & $133.7^{\mathrm{a}}$ & 4.95 & $0.80^{\text {abcd }}$ & $0.39^{\mathrm{abc}}$ & 0.05 & $0.29^{\mathrm{bcd}}$ & 0.01 & 1.56 & 51.8 & $18^{\mathrm{a}}$ \\
\hline & 180 & $146.3^{\mathrm{a}}$ & 5.13 & $0.58^{\text {bcd }}$ & $0.26^{\text {cde }}$ & 0.01 & $0.25^{\text {bcd }}$ & 0.00 & 1.61 & 50.4 & $20^{\mathrm{abc}}$ \\
\hline \multirow[t]{4}{*}{$5 \mathrm{~L}$} & 90 & $218.1^{\mathrm{b}}$ & 4.99 & $1.00^{\mathrm{a}}$ & $0.41^{\mathrm{ab}}$ & 0.03 & $0.46^{\mathrm{ab}}$ & 0.02 & 1.89 & 53.0 & 24 abcd \\
\hline & 120 & $223.4^{\mathrm{b}}$ & 4.95 & $0.94^{\mathrm{ab}}$ & $0.36^{\text {abcd }}$ & 0.02 & $0.45^{\mathrm{abc}}$ & 0.02 & 1.85 & 49.3 & 25 abcd \\
\hline & 150 & $217.5^{\mathrm{b}}$ & 4.99 & $0.85^{\mathrm{abc}}$ & 0.30 bcde & 0.07 & $0.40^{\mathrm{abc}}$ & 0.02 & 2.01 & 56.4 & $29 \mathrm{de}$ \\
\hline & 180 & $210.3^{\mathrm{b}}$ & 5.00 & $1.11^{\mathrm{a}}$ & $0.86^{\text {abcd }}$ & 0.05 & $0.59^{\mathrm{a}}$ & 0.03 & 2.38 & 59.5 & 34 ef \\
\hline \multirow[t]{4}{*}{$6 \mathrm{~L}$} & 90 & $163.4^{\mathrm{a}}$ & 5.52 & $0.57^{\text {bcd }}$ & $0.24^{\mathrm{de}}$ & 0.02 & $0.17^{\mathrm{a}}$ & 0.03 & 2.25 & 73 & 28 bde \\
\hline & 120 & $164.7^{\mathrm{a}}$ & 5.34 & $0.62^{\text {bcd }}$ & $0.21^{\mathrm{e}}$ & 0.13 & $0.17^{\mathrm{a}}$ & 0.02 & 1.57 & 72.5 & $31^{\text {de }}$ \\
\hline & 150 & $166.2^{\mathrm{a}}$ & 5.49 & $0.54^{\text {cd }}$ & $0.20^{\mathrm{e}}$ & 0.04 & $0.24^{\mathrm{cd}}$ & 0.01 & 2.02 & 66.5 & $39^{f}$ \\
\hline & 180 & $155.9^{\mathrm{a}}$ & 5.52 & $0.45^{\mathrm{cd}}$ & $0.18^{\mathrm{e}}$ & 0.28 & $0.18^{\mathrm{d}}$ & 0.01 & 1.75 & 73.7 & $47^{\mathrm{g}}$ \\
\hline SEM & & 11.9 & 0.66 & 0.009 & 0.03 & 0.03 & 0.51 & 0.007 & 0.06 & 6.51 & 1.90 \\
\hline Regrowth & & $<0.001$ & $<0.001$ & $<0.001$ & $<0.001$ & 0.30 & $<0.001$ & 0.007 & 0.009 & $<0.001$ & $<0.001$ \\
\hline Storage & & 0.04 & 0.59 & 0.048 & 0.001 & 0.48 & 0.12 & 0.81 & 0.02 & 0.07 & $<0.001$ \\
\hline $\begin{array}{l}\text { Regrowth } \mathrm{x} \\
\text { Storage }\end{array}$ & & 0.031 & 0.69 & 0.005 & 0.007 & 0.08 & 0.003 & 0.18 & 0.06 & 0.77 & 0.001 \\
\hline
\end{tabular}

* Different notation in the same column differed significally $(\mathrm{P}<0.05), \mathrm{SEM}=$ standard error of means, $\mathrm{BC}=$ buffering capacity, meq $=$ milli equivalent, $\mathrm{g}=$ gram, $\mathrm{DM}=$ Dry matter; $\mathrm{VFA}=$ volatile fatty acid, $\mathrm{NH}_{3}-\mathrm{N}=$ ammonia nitrogen 


\subsection{Nutritive value of plantain silage}

Plantain silage at early harvested had the highest DM percentage followed by $6 \mathrm{~L}$ and $5 \mathrm{~L}$ (Table 5). Regrowth stage affected the dry matter percentage $(\mathrm{P}<0.001)$. The value of organic matter was below $90 \%$ and increasing regrowth stage resulted in higher organic matter. The regrowth stage and storage duration affected the organic matter.

The ADF and NDF increased with the increased regrowth stage and storage duration. Plantain silage ADF were below $40 \%$ and the NDF were below 52\%. For ADF and NDF, there was an interaction between maturity and storage duration for ADF and NDF. The delay harvest reduced crude protein content and regrowth stage influenced the crude protein of plantain silage. The average crude protein was low $(<15 \%)$, although storage duration did not change the value of the silage protein.

The highest value of DM digestibility of plantain silage was at the 4L stored for 90 days with the value was lower than $67 \%$. The extension of regrowth stage and storage duration reduced the DM digestibility. The ME value was also low ( $<10 \mathrm{MJ} \mathrm{ME} / \mathrm{kg} \mathrm{DM})$ and was affected by regrowth stage and storage duration. During ensiling, aucubin and catalpol disappeared, only acteoside had a tiny amount remaining at the $4 \mathrm{~L}$ plantain silage $(0.05 \%)$ at 90 days of storage duration and more than four times higher at 180 days. Plantain silage at early regrowth stage contained the highest acteoside.

A biological measurement of a nutrient is a nutritive value (NV) of feeds. Feeds nutritive value [31]. Metabolizable energy and digestibility content of feed is often used to define nutritive value [32]. The digestibility and Metabolizable energy of plantain silage in this study was not high. The In vitro digestibility was 53 to $67 \%$ and the ME was 7.6 to 9.2 MJ ME kg DM. High quality silage is used to support $30-50 \%$ of an animal energy requirement as a feed supplement [33]. Feeds digestibility that lower than $70 \%$ will be less able to support maintenance and production of livestock [34]. Low quality silage can be caused by the low quality of fresh forage and its management or it could be the losses of nutrition during fermentation process.

This current study showed that early harvest plantain in warm temperature resulted in better quality than later harvested plantain $(\mathrm{P}<0.05)$. It meant that pre harvest management had a large effect on quality of silage. However, the digestibility of early harvested plantain was lower than desired level although this value was higher compared to the result found by [35]. The low digestibility of plantain silage was likely explained by the high seed head content and of NDF, which more than $40 \%$.

Another nutritive content that important to animal is protein. The protein content of plantain silage in this study was low, less than $13 \%$, even at the early stage of maturity. Interestingly, the $\mathrm{CP} \%$ of the silage was higher than the $\mathrm{CP}$ in the fresh forage. The reason for this is likely to be the result of high use of sugar substrates relative to $\mathrm{N}$ substrate by silage bacteria. As a result, this fraction decreases resulting in an increase in protein or fibre fractions, or both.

Longer storage duration decreased DMD [11]. This current study showed that storage duration up to 120 days was the good duration to store plantain silage. The DMD decreased by about $5 \%$ between 90 and 120 days compared to the DMD of wilted plantain. DM losses from digestible material because of the conversion of sugars to VFA and $\mathrm{CO} 2$ by microbe [8]. Storage duration reduced energy availability as well, but it did not affect crude protein content. 
Table 5. Effect of regrowth stage and storage duration to nutritive value of plantain four leaves appearance (4L), five leaves appearance (5L)

\begin{tabular}{|c|c|c|c|c|c|c|c|c|c|c|c|c|}
\hline Treatment & $\begin{array}{c}\text { Storage } \\
\text { duration } \\
\text { (day) }\end{array}$ & $\begin{array}{l}\text { DM } \\
(\%)\end{array}$ & $\begin{array}{l}\mathrm{OM} \\
(\%)\end{array}$ & $\begin{array}{l}\text { NDF } \\
(\%)\end{array}$ & $\begin{array}{c}\text { ADF } \\
(\%)\end{array}$ & $\begin{array}{l}\text { Crude } \\
\text { protein } \\
(\%)\end{array}$ & $\begin{array}{c}\text { DMD } \\
(\%)\end{array}$ & $\begin{array}{c}\text { DOMD } \\
(\%)\end{array}$ & $\begin{array}{c}\mathrm{ME} \\
(\mathrm{MJME} / \\
\mathrm{kgDM})\end{array}$ & $\begin{array}{c}\text { Aucubin } \\
(\mathrm{mg} / \mathrm{g})\end{array}$ & $\begin{array}{c}\text { Catalpol } \\
(\mathrm{mg} / \mathrm{g})\end{array}$ & $\begin{array}{c}\text { Acteoside } \\
(\mathrm{mg} / \mathrm{g})\end{array}$ \\
\hline \multirow[t]{4}{*}{$4 \mathrm{~L}$} & 90 & 36.3 & $84.4^{b}$ & 40.3 & $28.5^{\mathrm{g}}$ & $16.5^{\mathrm{f}}$ & $66.9^{d}$ & 57.0 & 9.18 & 0 & 0 & $0.53^{\mathrm{b}}$ \\
\hline & 120 & 37.9 & $81.7^{\mathrm{a}}$ & 42.1 & $31.1^{\mathrm{f}}$ & $13.9^{\mathrm{e}}$ & $62.2^{b c}$ & 53.5 & 8.56 & - & - & - \\
\hline & 150 & 36.8 & $85.6^{\text {bc }}$ & 44.8 & 32.1 ef & $14.2^{\mathrm{e}}$ & $62.7^{b c}$ & 55.1 & 8.81 & - & - & - \\
\hline & 180 & 38.7 & $85.7^{b c}$ & 45.6 & $33.0^{\mathrm{def}}$ & $13.4^{\mathrm{de}}$ & $62.2^{b c}$ & 55.0 & 8.80 & 0 & 0 & $2.27^{\mathrm{a}}$ \\
\hline \multirow[t]{4}{*}{$5 \mathrm{~L}$} & 90 & 27.7 & $88.6^{\mathrm{d}}$ & 45.9 & $34.2^{\text {cde }}$ & $13.1^{\text {bcde }}$ & $62.7^{b c}$ & 54.5 & 8.72 & - & - & - \\
\hline & 120 & 28.0 & $88.6^{\mathrm{d}}$ & 46.2 & $36.1^{\mathrm{bc}}$ & $14.1^{\mathrm{e}}$ & $64.2^{\mathrm{cd}}$ & 56.9 & 9.11 & - & - & - \\
\hline & 150 & 28.2 & $87.9^{\mathrm{cd}}$ & 46.8 & $34.6^{\mathrm{cd}}$ & $13.3^{\text {cde }}$ & $61.2^{b c}$ & 53.8 & 8.60 & - & - & - \\
\hline & 180 & 28.7 & $88.0^{\mathrm{cd}}$ & 48.3 & $36.0^{\mathrm{bc}}$ & $13.0^{\text {abcd }}$ & $60.2^{b}$ & 53.0 & 8.48 & - & - & - \\
\hline \multirow[t]{4}{*}{$6 \mathrm{~L}$} & 90 & 33.4 & $88.9^{\mathrm{a}}$ & 51.5 & $39.3^{a}$ & $11.4^{\mathrm{a}}$ & $55.1^{\mathrm{a}}$ & 48.4 & 7.74 & 0 & 0 & $0.53^{\mathrm{a}}$ \\
\hline & 120 & 30.8 & $87.6^{\mathrm{cd}}$ & 50.9 & $38.2^{a b}$ & $11.5^{\mathrm{ab}}$ & $55.7^{\mathrm{a}}$ & 47.2 & 7.55 & - & - & - \\
\hline & 150 & 32.9 & $88.1^{\mathrm{cd}}$ & 52.0 & $38.0^{a b}$ & $11.6^{\mathrm{abc}}$ & $53.0^{\mathrm{a}}$ & 45.4 & 7.27 & - & - & - \\
\hline & 180 & 32.5 & $88.5^{\mathrm{d}}$ & 52.8 & $39.6^{\mathrm{a}}$ & $11.8^{\text {abcd }}$ & $54.4^{\mathrm{a}}$ & 47.6 & 7.6 & 0 & 0 & $0.39^{\mathrm{b}}$ \\
\hline SEM & & 1.36 & 0.61 & 0.91 & 1.08 & 0.77 & 0.95 & 0.72 & 0.23 & - & - & 0.07 \\
\hline $\begin{array}{l}\text { Regrowth } \\
\text { Storage } \\
\text { Regrowth } \\
\text { X Storage }\end{array}$ & & $\begin{array}{c}<0.001 \\
0.80 \\
<0.78\end{array}$ & $\begin{array}{c}0.006 \\
<0.024 \\
<0.001\end{array}$ & $\begin{array}{c}<0.001 \\
<0.001 \\
0.306\end{array}$ & $\begin{array}{c}<0.001 \\
<0.009 \\
0.033\end{array}$ & $\begin{array}{c}<0.001 \\
0.221 \\
0.021\end{array}$ & $\begin{array}{c}<0.001 \\
0.002 \\
0.036\end{array}$ & $\begin{array}{c}<0.001 \\
0.145 \\
0.065\end{array}$ & $\begin{array}{c}<0.001 \\
0.145 \\
<0.065\end{array}$ & $\begin{array}{l}- \\
- \\
-\end{array}$ & $\begin{array}{l}- \\
- \\
-\end{array}$ & $\begin{array}{c}<0.001 \\
0.002 \\
<0.001\end{array}$ \\
\hline
\end{tabular}

* Different notation in the same column differed significantly $(\mathrm{P}<0.05), \mathrm{SEM}=$ standard error of means, $\mathrm{DM}=$ dry matter, $\mathrm{OM}=\mathrm{Organic}$ matter, $\mathrm{NDF}=$ neutral detergent fibre, $\mathrm{ADF}=$ acid detergent fibre, $\mathrm{DMD}=$ dry matter digestibility, $\mathrm{DOMD}=$ Digestible organic matter in dry matter, $\mathrm{ME}=$ metabolisable energy, $\mathrm{MJ}=$ mega joule, $\mathrm{mg} / \mathrm{g}=$ milligram $/$ gram, $\mathrm{SEM}=$ standard error of means, $\mathrm{P}=$ probability 


\section{Conclusion}

In warm temperature, the fermentation characteristics and nutritive value of plantain silage was not in high quality. However, the sweet smell and did not seem to be spoiled, indicating safe fermentation. Early stage of maturity of plantain resulted in better fermentation characteristics and nutritive value compared with at the late stage of maturity. Besides, plantain silage could be stored up 120 days. Thus, ensiling plantain at the early stage of maturity was recommended to be used at the commercial scale.

\section{References}

1. J. Pijlman, S.J. Berger, F. Lexmond, J. Bloem, J.W. Van Groenigen, E.J.V. Visser, J.W. Erisman, N. Van Eekeren, New Zeal. J. Agric. Res. 1-17, doi: 10.1080/00288233.2019.1698620 (2019)

2. L.A. Box, G.R. Edward, R.H. Bryant, Milk production and urinary nitrogen excretion of dairy cows grazing perennial ryegrass-white clover and pure plantain pasture, in Proceeding of the $\mathbf{7 6}^{\text {th }}$ New Zealand Society of Animal Production, pp 18-21, New Zealand Society Animal Production (2016)

3. S.L. Woodward, C.D. Waugh, C.G. Roach, D. Fynn, J. Phillips, Are diverse species mixtures better pastures for dairy farming, in Proceedings of the $\mathbf{7 5}^{\text {th }}$ Conference of the New Zealand Grassland Association, pp 79-84, New Zealand Grassland Association (2013)

4. V.K.Totty, S.L. Greenwood, R.H. Bryant, G.R. Edwards, J. Dairy Sci. 96, 1, 141-149, doi:10.3168/jds.2012-5504 (2013)

5. M. Pol, K. Schimdtke, S. Lewandowska, Open Agric. 6, 479-488, doi : 10.15.15/opag.2021'0035 (2021)

6. A.V. Stewart, Plantain (Plantago lanceolata)-a potential pasture species, in Proceedings of the $\mathbf{5 8}^{\text {th }}$ Conference of the New Zealand Grassland Association, pp 7786, New Zealand Grassland Association (1996)

7. B. Mahanna, L.E. Chase, Silage Sci. Technol. 42, 855-895, doi:10.2134/agronmonogr42.c19 (2003)

8. T.F. Bernardes, J.L.P. Daniel, A.T. Adesogan, T.A. McAllister, P. Drouin, L.G. Nussio, Y. Cai, J. Dairy Sci. 101, 4001-4019, doi:10.3168/jds.2017-13703 (2018)

9. Z.L.Xie, T.F. Zhang, X.Z. Chen, G.D. Li, J.G. Zhang, Asian-Australasian J. Anim. Sci. 25, 10, 1374, doi:10.5713/ajas.2012.12084 (2012)

10. B .Z. Saricicek, B.Yildirim, Z. Kocabas, E.O. Demir, J. Inst. Sci. Tech. 6, 177-183 (2016)

11. Z.G. Weinberg, Y. Chen, Anim. Feed Sci. Technol. 185, 3-4, 196-200, doi:10.1016/j.anifeedsci.2013.08.009 (2013)

12. J. Moran, Tropical dairy farming: feeding management for small holder dairy farmers in the humid tropics (CSIRO Publishing, Australia, 2005)

13. G. Ashbell,T. Kipnis, M. Titterton, Y. Hen, A. Azrieli, Z. Weinberg, Anim. Feed Sci. Technol. 91, 3, 213-222, doi:10.1016/S0377-8401(01)00239-5 (2001)

14. M.J. Playne, P. McDonald, J. Sci. Food Agric. 17, 6, 264-268, doi:10.1002/jsfa.2740170609 (1966)

15. AOAC, Fibre (Acid Detergent) and lignin in animal feed official methods of analysis $\left(15^{\text {th }}\right.$ Edition) (Association of Official Analytical Chemists, doi:10.1016/00032670(91)87088-O, 1990) 
16. P.J. Van Soest, J.B. Robertson, B.A. Lewis, J. Dairy Sci. 74, 10, 3583-3597, doi:10.3168/jds.S0022-0302(91)78551-2 (1991)

17. C. Pollock, T. Jones, New Phytol. 83, 1, 9-15. doi:10.1111/j.1469-8137.1979.tb00720.x (1979)

18. Y. Tamura, S. Nishibe, Agric. Food Chem. 50, 2514-2518, doi:10.1021/jf011490x (2002)

19. T. Clarke, P. Flinn, A. McGowan, Grass Forage Sci. 37, 2, 147-150, doi:10.1111/j.1365-2494.1982.tb01590 (1982)

20. A. Powell, P. Kemp, I. Jaya, M. Osborne, Establishment, growth and development of plantain and chicory under grazing, in Proceedings of the $\mathbf{7 6}^{\text {th }}$ Conference of the New Zealand grassland association, New Zealand Grassland Association (2007)

21. K. Bolsen, G. Ashbell, Z. Weinberg, Asian-Australasian J. Anim. Sci. 9, 5, 483-494 (1996)

22. R. Muck, K.J. Shinners, Conserved forage (silage and hay): progress and priorities, in Proceedings of the International Grassland Congress, Vol 19 (2001)

23. S. Jiang, R.H. Bryant, J. Jiao, R. Tung. New Zeal. J. Anim. Sci. Prod. 79, 174-176 (2019)

24. G. Borreani, E. Tabacco, L. Cavallarin, J. Dairy Sci. 90, 10, 4701-4706, doi:10.3168/jds.2007-0310 (2007)

25. J.M. Wilkinson, D.R. Davies, Grass Forage Sci. 68, 1-19, doi : 10.1111/j.13652494.2012.00891.x (2012)

26. L. Kung, R. Shaver, Focus Forage. 3, 13, 1-5 (2001)

27. J. Isselstein, P. Daniel, The ensilability of grassland forbs, in Grassland and land use systems, Proc. 16 ${ }^{\text {th }}$ Gen Meet. Europ. Grassl. Federation. Grado, Italy. 451-455 (1996)

28. S. Navarrete, P.D. Kemp, S.J. Pain, P.J. Back. Anim. Feed Sci. Technol. 222, 158-167, doi:10.1016/j.anifeedsc1.2016.10.008 (2016)

29. Z.G. Weinberg, R.E. Muck, FEMS Microbiol. Rev. 19, 1, 53-68, doi:10.1111/j15746976.1996.tb00253.x (1996)

30. G. Pahlow, H. Honig, The role of microbial additives in the aerobic stability of silage, in Proceedings of the $\mathbf{1 5}^{\text {th }}$ General Meeting of EGF, 149-152, The Netherlands (1994)

31. K.L Blaxter, J. Dairy Sci. 39, 10, 1396-1424, doi:10.3168/jds.S0022-0302(56)94865-2 (1956)

32. CSIRO, Nutrient requirements of domesticated ruminants (CSIRO publishing, Collingwood VIC Australia, (2007)

33. M. Castle, W. Retter, J. Watson, Grass Forage Sci. 35, 3, 219-225, doi:10.1111/j.13652494.1980.tb01515.x (1980)

34. G.C. Waghorn, J.L. Burke, E.S. Kolver, Principles of feeding value, In Pasture and Supplements for Grazing Animals, 35-59 (New Zealand Society of Animal Production, New Zealand, 2007)

35. M. Raeside, Z. Nie, J. Lamb, A. Byron, R. Behrendt, Nutritive value of silage from perennial ryegrass, plantain and lucerne pastures in South west Victoria, in Proceeding of the $\mathbf{1 6}^{\text {th }}$ Australian Agronomy Congress, Australian Agronomy (2012) 